\title{
NOTARIADO
}

\section{Sucesiones en sede notarial}

\author{
Sandra Johana González Rivas ${ }^{1}$
}

\begin{abstract}
Resumen
Introducción: En Paraguay, las sucesiones se tramitan en sede judicial. Sin embargo, en otros países como Brasil, Bolivia, México, España, entre otros, las sucesiones en sede notarial, constituyen un hecho jurídico. Al respecto, cabe preguntarse, ¿ ¿s realmente necesario su tramitación por los Tribunales cuando todos los herederos están de acuerdo, no hay reclamos de terceros y existe conformidad de todos para la partición de los bienes?, ¿Puede el Notario, considerando su imparcialidad y otras características similares a las de un Juez, intervenir en casos de este tipo?
\end{abstract}

Objetivo: Determinar la factibilidad de implementar en Paraguay las sucesiones en sede notarial.

Material y Método: Revisión bibliográfica de doctrina y legislación comparada. Resultados: En Paraguay, es posible la implementación de una normativa legal que permita realizar la tramitación de las sucesiones ante Notario cuando exista acuerdo entre herederos, no haya reclamos de terceros ni menores de edad o incapaces y exista conformidad en cuanto al modo de realizar la partición de los bienes, puesto que toda ausencia de conflicto es compatible con la función notarial.

Conclusiones: La adopción legal de esta competencia contribuirá a la descongestión del ámbito judicial, favorecerá la celeridad de la tramitación sucesoria, posibilitará el inicio y la finalización de las sucesiones en un solo lugar, con la elección de un profesional de confianza, especializado en materia notarial y registral, con horario de atención y ubicación más accesible que el brindado por los Juzgados. Todo lo cual, se traduce en mayor seguridad jurídica preventiva, atendiendo además al estricto régimen de responsabilidades del Notario e imposición de sanciones al mismo en caso de incumplimiento de sus deberes legales.

En efecto, sería necesario regular aspectos legales tales como: 1) la tramitación de la sucesión intestada ante Notario, bajo patrocinio de letrado, o mediante Abogado con poder especial, 2) Mantener la competencia territorial departamental del Notario, regulada en la Ley 2335/03, para tramitar las

1. Universidad Iberoamericana, Facultad de Derecho y Ciencias Sociales. San Lorenzo.

Es un Proyecto de Investigación financiado por una mini subvención por la Red de Intervenciones de Programas de Capacitación en Epidemiología e Salud Pública (TEPHINET). Fue presentado en la XI Conferencia Científica Regional de TEPHINET, en Cartagenas-Colombia, en 15-18 de mayo del 2018.

E-mail: escribanasandragonzalez925@hotmail.com

DOI: $10.26885 /$ rcei.foro.2018.110 


\section{Sucesiones en sede notarial. González Rivas}

sucesiones intestadas en el área correspondiente al departamento del último domicilio del causante, 3) la creación de un registro sucesorio dependiente de la Dirección General de los Registros Públicos, a fin de evitar duplicidad de tramitaciones, 4) la publicación de edictos a través de medios de gran difusión, incluyendo medios electrónicos, 5) la intervención de un defensor público en caso de requirentes insolventes, 6) la regulación de plazos legales, como ser la duración de cada etapa o el tiempo máximo dentro del cual debería de culminar el proceso sucesorio.

En consecuencia, se insta a las autoridades nacionales a impulsar las reformas legislativas necesarias, para beneficio de la ciudadanía en general.

Palabras clave: notario, sucesiones, Paraguay.

\section{Referencias}

Bolivia. Ley $N^{\circ} 483$, Del Notariado Plurinacional, promulgada el 25 de enero de 2014.

Comisión Nacional para la Reforma de Justicia. (2016). Anteproyecto de Código de Organización Judicial.

España. Ley $N^{\circ}$ 15, de fecha 2 de julio de 2015.

Paraguay. Ley 879/81, Código de Organización Judicial y modificaciones.

Paraguay. Ley № 1.183/85, Código Civil. 